\title{
The Fuhrer's Face: Inglourious Basterds and Quentin Tarantino's Confrontation with Nazis, Hitler and Fascist Aesthetics in Hollywood Cinema
}

\author{
Conrad Leibel
}

This paper is an in depth visual and theoretical analysis of Quentin Tarantino's 2009 film Inglourious Basterds. The central questions with which the essay contends are how Quentin Tarantino represents Nazis within his film, as represented by Colonel Hans Landa and Adolf Hitler and where the film fits within the American tradition of representing Nazis on-screen. Inglourious Basterds creates an argument that the Nazi regime itself was a type of performance; the regime's politics are explicitly theatrical, and the only weapon capable of taking it down is an equally powerful theatrical machine: Hollywood.

Nazism and the Third Reich have occupied the cinematic imaginations of both Europe and North America since roughly two years before the Second World War had erupted. In the initial war and post-war years, the figure of the Nazi had functioned as an enemy within Hollywood narratives, as well as the post-war European anti-fascist films. As the historical referent of the Third Reich has become increasingly distanced from future generations, the symbol of the Nazi has devolved into a floating signifier, that is, a signifier that has been disconnected from the original historical referent and has come to signify a variety of somewhat related and unrelated symbols. The most popular incarnation of the Nazi as a floating signifier is American culture's appropriation of the image of Adolf Hitler as a symbol of universal evil, a figure which allegorically represents evil incarnate in human form. Film-makers have contended with this Americanized image of Hitler since the end of the World War and, with the global media's coverage of Hitler's final solution, attempts to portray Hitler as otherwise have been looked on as callous and insensitive to the victims of Hitler, the Nazi Party and German citizens' crimes. European cinema, however, has favoured a representation of Hitler as a "seducer" or "demon" who had held Europe under a spell while most Germans take the role of a type of hypnotized victim, who is absolved of the guilt of being complicit with the rise and maintenance of the Third Reich. The twenty-first century has been characterized by an increasing normalization of Nazism and Hitler in both German and American popular culture. Whereas a long-standing taboo on representing Hitler in film (with the exception of Syberberg's Hitler and the "Hitler Wave" films of the 1970's) once stood in Germany, the first decade of the twenty- first century has been characterized through an increasing normalization of representing Hitler in cinema. After several decades of Hollywood Nazi films, Quentin Tarantino's 2009 film Inglourious Basterds makes the exception. Inglouroious Basterds is a film that directly engages in contesting traditional modes of representing Hitler and Nazism in both Hollywood and European cinema and represents a pastiche of Hollywood and Nazi aesthetics in its purpose to lay bare the fascist forms used by the cinema of the Third Reich, which Hollywood has appropriated.

Inglourious Basterds is the inheritor in a long tradition of Hollywood anti-Nazi films, which have developed an "enemy friend distinction" between Nazis and Americans. ${ }^{1}$ This distinction

\footnotetext{
${ }^{1}$ Sabine Hake, Screen Nazis: Cinema, History, and Democracy (Madison: University of Wisconsin Press, 2012), 21.
} 
maintains that the Nazi's primary role in the film's narrative is to "personify the monopoly of violence and the power over life and death associated with the totalitarian state." 2 The Nazi figure also performs the "suspension of the rule of law" and replaces it with "total surveillance., These Nazis are stereotypical villains who enact the "negative position" in a series of binaries which establish American Democracy as the benevolent counterpart to Nazism (ie. Liberalism vs. totalitarianism, individualism vs. communalism, humanism vs. collectivism, freedom of speech vs. censorship, religion vs. ideology, love vs. sexuality, monogamy vs. promiscuity and life vs. death). ${ }^{5}$ These films worked to transform American audiences into "citizens" through the audience's recognition of the Nazi stereotypes as enemies; the Nazis in these films often took the forms of "the party member", "the officer", "the sympathizer", and "the collaborator."7 Each of these stereotypes command the "intense aversions" of the audience as the Nazi is transformed into a "preferred object of loathing or ridicule by the spectator." Examples of these characters include Major Heinrich Strasser (played by Conrad Veidt) in Casablanca, Peter Lorre and Conrad Veidt's characters in All Through the Night, and the Great Dictator, in Charlie Chaplin's film of the same name. Whereas the first two are threatening enemies with whom the moral American Humphrey Bogart must battle, Charlie Chaplin's Great Dictator begins as an object of ridicule for the audience and, in the final scene, Chaplin transforms his satire of Hitler and Nazism into a (kitschy) plea for world-wide democracy as he manipulates the audience's identification for him as "Charlie Chaplin" as a means of prodding the audience to take a political stand against Nazism. ${ }^{10}$ Tarantino's film responds to the anti-Nazi tradition of Hollywood cinema through blurring the distinctions between the American soldiers and the Nazis as he provides his audience with a grotesque burlesque of violence.

Quentin Tarantino's 2009 film Inglourious Basterds is an absurd response to cinematic conventions regarding representations of Nazism and the Holocaust in that it is linked with the literary movement of the theatre of the absurd in its rejection of the "certitudes and unshakeable basic assumptions of former ages."11 Tarantino rejects the grand historical narrative of WWII through creating a fantastical alternative history which takes place outside of traditional narratives of the Second World War. Tarantino's film has been popularly quipped as a Jewish revenge fantasy. The film is a post-modern pastiche of cinematic quotations to other films, as Tarantino appropriates music and visuals from other films (such as Ennio Morricone's score for the Man with No Name trilogy). The Jewish revenge fantasy occurs within two separate narrative frames, the first is Aldo Raine's assembly of a group of Jewish-American soldiers, called the "basterds", to whom Aldo declares that each of the soldier's owes him "100 Nazi scalps"12; the purpose of the basterd's mission is to instill fear into Nazis through intense

\footnotetext{
${ }^{2}$ Ibid.

${ }^{3}$ Ibid.

${ }^{4}$ Ibid., 35.

${ }^{5}$ Ibid.

${ }^{6}$ Ibid.

${ }^{7}$ Hake, 41.

${ }^{8}$ Ibid.

${ }^{9}$ Ibid.

${ }^{10}$ The Great Dictator, directed by Charlie Chaplin (United Artists, 1941).

${ }^{11}$ Martin Esslin, The Theatre of the Absurd (London: Methuen, 2001), 23.

${ }^{12}$ Inglourious Basterds, directed by Quentin Tarantino (The Weinstein Company, 2009)
} 
displays of violence (by scalping and mutilating Nazi officials). The basterds narrative of Tarantino's film upsets the balance of the friend-enemy distinctions on which Hollywood antiNazi narratives rely, through careful camerawork. In the sequence in which Aldo and the basterds are introduced, Aldo briefs the basterds on their mission and goes on a tirade against the German: "And the German will be sickened by us. And the German will talk about us. And the German will fear us." ${ }^{13}$ Aldo incessantly continues this monologue in which he claims that "Nazi ain't got humanity." "The American characters cannot seem to make the distinction between Nazis and Germans throughout the film and Aldo's cartoonish monologue serves as a useful reference point. The monologue troubles the separation between Nazis and Americans in that Aldo's rhetoric of referring to "the German" is comparable to how Nazi propaganda would represent Jews under the singular type of "the Jew" through films such as Der Ewige Jude, which established "The Jew" as a singular character type to which all Jews conform through their "parasitic nature" and "degenerate art."."

Tarantino further disrupts the Hollywood friend-enemy distinction between Americans and Nazis in his displacement of viewer identification patterns. In the first scene where Tarantino presents the basterds in-action, Aldo is about to call out "the Bearrrrr Jew" (also known as Sergeant Donny Donnowitz) to come out of his lair to bash in the head of a Nazi officer who is unwilling to divulge information which will place his fellow German soldiers at risk. Tarantino places the camera at eye level with the Nazi officer as he looks up at the Bear Jew from a low angle; the low angle makes Donny look monstrous and sadistic and compels the viewer to identify with the Nazi officer who is about to have his head beaten in. As soon as Donny begins to bash the officer's head, the camera pulls away into a long shot; the distance provokes the viewer into feeling alienated from the action which is taking place and the clubbing comes across as monstrous, even to an audience attuned to the image of the Nazi villain. As he beats the man's head in, Donny goes into frenzy and begins yelling a pseudo sports cast:

Teddy fuckin' Williams knocks it out of the park! Fenway Park on its feet for Teddy fuckin' Ballgame! He went yardo on that one, out to fuckin' Lansdowne Street! ${ }^{16}$

Donny's "sportscast" comes across to the audience as belligerent and brutish when counterpoised with the brutal violence that is taking place on-screen. The American basterds are here depicted as sadistic, infantile men who are unable to distinguish between games and horrific violence. Though Tarantino is usually regarded as a director who glorifies acts of violence, the representation of violence perpetrated against the German officer in this scene is unsettling and upsets traditional images associated with the American troops, as depicted in American propaganda films during the Second World War. Donny's brutal murder of the German officer is described by Aldo as being "the closest we ever get to going to the movies" and makes the audience complicit in the brutality, which Tarantino is representing. ${ }^{17}$

\footnotetext{
${ }^{13}$ Ibid.

${ }^{14}$ Ibid.

${ }^{15}$ Der Ewige Jude, directed by Fritz Hippler (Germany: D.F.G., 1938)

${ }^{16}$ Tarantino, Inglourious Basterds.

${ }^{17}$ Ibid.
} 
The second "Jewish Revenge" narrative layer in Inglourious Basterds is Shoshanna Dreyfus' plan to burn down her theatre and the main Nazi leaders along with it. Shoshanna's narrative opens the film in a scene where the SS Colonel Hans Landa questions a French dairy farmer about Jewish families who had formerly lived in the area. Prior to the film's opening sequence, the inter-titles announce: "Once upon a time... in Nazi occupied France." ${ }^{\prime 18}$ These inter-titles place the film within the realm of fantasy and indicate that the film does not intend to create an accurate representation of life in Nazi occupied France; it is the material of a fairy tale (Tarantino will later return to this iconography when Hans Landa plays the sadistic Prince Charming to Bridget von Hammersmark's Cinderella when the actress loses her shoe). The scene opens with an Ennio Morricone score playing, in deliberate reference to the Sergio Leone spaghetti westerns. When the SS Colonel, Hans Landa, arrives to the Frenchman's cabin, he acts most cordial and asks if the man would be so kind as to let him into his house. When Landa arrives into the house, a tense interrogation scene follows in which Landa displays his sense of courtly manners and handle over multiple languages as he prods the man into revealing the whereabouts of a group of Jews, to whom the Frenchman has offered shelter. The tone shifts immediately when Landa discovers this information; he invites his SS men inside and the three SS members frantically shoot at the floor-boards, desecrating the house and killing all (but one) Jew. Shoshanna escapes Landa's massacre only by the fluke chance that Landa's pistol has run out of ammo. The Nazis execute the first act of violence in Tarantino's film, thereby marking themselves as enemies; however, Landa's complexity as a character (later in the film, Bridget von Hammersmark makes the mistake of assuming that Nazis have no handle on Italian, and Tarantino makes her pay for her assumption of the Nazi stereotype) indicates that he is the exception amongst his cartoonish, stereotypical peers and that Tarantino complicates the traditional enemy-friend distinction.

The character of the SS Colonel Hans Landa draws on the stock character of the "cultured Nazi" 19 of Hollywood films. This character has been represented by Orson Welles' roles in both The Stranger and The Third Man. This character portrays the Nazi as a formidable foe who is both "charming and seductive.", 20 This character would later be replaced by the "heel-clicking Nazi" of post-war Hollywood's imagination; however, Landa complicates this character type through his own inability to be governed by a single ruling party and the directorial status which Tarantino provides the character with. ${ }^{21}$ Landa toys with each of the characters in their own plots; first with the farmer Lapadite, with whom he plays a sadistic game of cat and mouse in which he reveals that he has known that the Dreyfuses were underneath the floorboards since he had entered the house, yet continues to ask the farmer questions in spite of his knowledge. When he confronts Bridget von Hammersmark, Landa already knows that Bridget was at the scene of the crime, yet enjoys the satisfaction of witnessing her attempt to justify her leg cast, as he bursts out laughing when she describes that she obtained her injury whilst climbing mountains, and

\footnotetext{
${ }^{18}$ Ibid.

${ }^{19}$ Oliver Speck, "Is Tarantino Serious? The Twofold Image of the Auteur and the State of Exception" in Quentin Tarantino's Inglourious Basterds: A Manipulation of Metacinema, ed. Robert Dassanowsky (New York: Continuum, 2012), 203.

${ }^{20}$ Ibid.

${ }^{21}$ Tarantino himself has stated in an interview with Cahiers $d u$ Cinema that Landa "is a director" and "my stand-in". Cahiers Du Cinema Editorial Board, "Entretien Avec Quentin Tarantino: On N'a Pas Besoin Du Dynamite Quand on a De La Pellicule," Cahiers Du Cinema, 646th ser. (June 2009), 15.
} 
then later strangles her when she attempts to speak after he has placed the shoe on her foot. At the end of the film, Landa writes himself into history as a moral American; the official press coverage will indicate that Landa has been a part of operation Kino from the very start and has been helping to save many lives through collaborating with the Americans in taking down Nazism. Landa's re-inscription of history implies that American history is tainted by the specter of Nazism; however, Landa fails to absolve himself as a Nazi when Raine graphically cuts a swastika into his scalp, with the camera's perspective aligned with Aldo. As a result, the spectator is implicated into this act of physically marking Landa as a Nazi. Landa's directorial efforts; however, are unable to control the revenge of Shoshanna Dreyfus.

Shoshanna's revenge is unique within the film as it is the only truly "subversive" 22 revenge narrative in the film, as it remains outside of Landa's ability to control. She begins her revenge in a sequence in which David Bowie's "Cat People" begins to play; the lyrics of the song continually express that revenge is like "putting out fire with gasoline" 23 . Shoshanna's revenge is revolutionary in that she writes herself into Nazi aesthetics (by literally editing her face into the Nazi film "Nation's Pride") rather than allowing her vengeance to be dictated by previously established fascist forms. Her revenge transcends the limits of her body (whereas the basterds' form of revenge relies on inscribing the German body) as she becomes the "face of Jewish vengeance." 24 Shoshanna's face is now a representation of "temporal ghostliness." 25 Her image continues to be projected beyond the confines of the screen as the projection space is burned along with her theatre. Shoshanna's revenge does not "seek to reassert the nuclear family" as traditional narratives of female vengeance often fall into (such as Tarantino's own Kill Bill franchise). ${ }^{26}$ Shoshanna's revenge is unique in that she is the only Jewish character in the film who grounds her violent act of revenge upon previous persecution and trauma, as she is the only Jew to escape Hans Landa's massacre at the opening of the film. Shoshanna's giant face recalls Dreyer's Passion de Jean d'Arc, in which the titular character's (played by Maria Falconnetti) face is prominently represented through close up, as the audience witnesses her anguish. The character's face breaks with cinematic tradition and laughs at the audience, which is a form of expression that is situated "outside of logic and reason.",27 The intrusion of the giant face undermines the logic and reason behind the aesthetics of the Third Reich; her face represents "the individual behind the mask" 28 and an unveiling of the truth and constructed-ness of the spectacle. Nazi aesthetics dictated that the ideal film must "spirit people away from the real world" and must, at all costs, avoid drawing attention to manipulation. ${ }^{29}$ Shoshanna's revenge draws her Nazi audience's attention to cinematic manipulation and destroys the Third Reich through its own aesthetic principles.

\footnotetext{
${ }^{22}$ Heidi Schlipphacke, "Inglourious Basterds and the Gender of Revenge," in Quentin Tarantino's Inglourious Basterds: A Manipulation of Metacinema, ed. Robert Dassanowsky (New York: Continuum, 2012), 128.

${ }^{23}$ Tarantino, Inglourious Basterds.

${ }^{24}$ Ibid.

${ }^{25}$ Schlipphacke, 129.

${ }^{26}$ Ibid., 125.

${ }^{27}$ Ibid., 129.

${ }^{28}$ Ibid.

${ }^{29}$ Eric Rentschler, The Ministry of Illusion: Nazi Cinema and Its Afterlife (Cambridge, MA: Harvard University Press, 1996), 217.
} 
In contrast to the omnipresence of Hitler and Nazis in American films, German cinema has been much more reluctant to have actors portraying the Fuhrer on-screen. Outside of G.W Pabst's The Last Ten Days, German cinema had produced only eleven films depicting Hitler out of more than a hundred on Charles Mitchell's list in the exhaustive catalogue raisonnée. ${ }^{30}$ Cinematic representations of Hitler have been more popular amongst American and British cinema, with some of the most well known performances being those of Charlie Chaplin, Alec Guinness and Anthony Hopkins. The problem with which filmmakers and actors must contend when portraying Hitler and the Nazis is that coming to terms with Hitler and Nazism also means coming to terms with his "filmic representation." ${ }^{31}$ Syberberg's Hitler - Ein Film aus Deutstchland attempted to confront the problem of the cinematic symbol of Hitler in cinema, as the film implies that Hitler himself is a "film from Germany", and Syberberg attempts to bring about the end of the mythologized Hitler "who is now a film.","32 The problem with representing Hitler is precisely that by reproducing his image, films can cave into the aesthetic which Hitler and Goebbels had constructed through the countless newsreels, films and recordings that were created with the goal of fostering "the Hitler myth. This allows the figures their ultimate wish by transforming them into eternal images on the silver-screen.

Martin Wuttke's portrayal of Hitler in Inglourious Basterds is quite possibly one of the most comical imaginings of a malevolent German Fuhrer. Hitler's first appearance in the film involves the character in a temper-tantrum, as he rants incessantly (He begins his monologue by repeatedly yelling "NEIN! NEIN!"). ${ }^{33}$ In the background is a giant cartoonish map of Europe, on which Nazi territories are marked in red with gold script and swastikas, and geographical accuracy is tossed aside. This map will later find its counterpart in Churchill's office, in which an incredibly detailed, yet flawed, map of Europe is located. In this scene, Tarantino disrupts traditional notions of benevolent, non-racist allies when Churchill will ask how Goebbels "is doing" in his war against "Jewish controlled" ${ }^{34}$ Hollywood cinema, a mode of thought associated with Nazi propaganda concerning the global Jewish conspiracy. Hitler is an object of ridicule within Tarantino's film; the character immediately assumes that "the Bear Jew" is a "golem" (a mythological creature from Jewish folklore) and evinces that he does not have a grasp on his own thoughts or actions. "Who and what is a lieutenant Butz?" Hitler asks of his protégés, after the two men remind their Fuhrer that he had earlier requested Lieutenant Butz to come to his office. ${ }^{36}$ In further cartoonish manner, Hitler is portrayed from low angle in order to emphasize the giant portrait of his self as a Teutonic knight which stands in behind of him (as he is dressed in the same garb as the portrait). This multiple layering of images of Hitler emphasizes that Tarantino is merely re-appropriating images of Hitler to new ends and that the Hitler whom we see in his film is a caricature of the representations which had come before. The Hitler of Inglourious Basterds is a "nouveau-riche warlord" who "attempts to insert himself significantly

\footnotetext{
${ }^{30}$ Martin A. Ruehl and Karolin Machtans. Hitler--films from Germany: History, Cinema and Politics since 1945 (New York: Palgrave Macmillan, 2012), 8.

${ }^{31}$ Ruehl, 8.

${ }^{32}$ Hans Jürgen Syberberg. Hitler, a Film from Germany (New York: Farrar Straus \& Giroux, 1982), 5.

${ }^{33}$ Tarantino, Inglourious Basterds.

${ }^{34}$ Tarantino, Inglourious Basterds.

${ }^{35}$ Ibid.

${ }^{36}$ Ibid.
} 
into history with a giant painting of a romantically caped likeness. ${ }^{, 37}$ Martin Wuttke's portrayal of the Fuhrer is a parody of the "Hollywood kitsch" fantasy representations of Hitler.

Tarantino is essentially relaying what Ian Kershaw has established in his seminal work, The Hitler Myth, namely that our constructions of Hitler are an achievement of "image-building" fostered by both "the masses" and those who "imposed" it on them. ${ }^{38}$ Kershaw's book discusses the image of the "heroic Hitler" (and the less heroic image which developed during the later war years) in Third Reich Germany; however, the principle of image building is crucial in understanding the form which Tarantino's Hitler takes, which is as the incarnate of earlier images of Hitler in Hollywood cinema. ${ }^{39}$ Tarantino underlies the fundamental impossibility of properly representing Hitler in cinema. In Seesslen's definition of fascist aesthetics, the hero must become an "eternal [and omnipresent] image" through death, an exit which Tarantino denies Hitler.

Shoshanna is the only character in the film that is capable of confronting Hitler on his own terms, that is, as a giant image. Tarantino presents Shoshanna's face in a shot/reverse shot pattern with Hitler's as he reacts in horror; a pattern which implies that the two "giant faces" are engaged in an exchange with each other over ownership of the film-space. Before he finds his end at the hand of Shoshanna and the basterds, Hitler demands that the projection be shut off, yet he is unable to control Shoshanna's dominance over the screen-space as her face remains on the screen and proclaims itself "the face of Jewish vengeance." ${ }^{41}$ In the finale of Tarantino's film, Hitler's image is no longer recognizable. Tarantino denies the spectator the pleasure of seeing Hitler die in a grandiose fashion by showing his face being grotesquely mutilated in a brief close up which lasts no more than two seconds. Hitler's image is unrecognizable as Donny Donnowitz riddles the Fuhrer's face with bullet holes, which prevents him from obtaining the satisfaction of becoming an eternal image. The sequence is shorn of any grandiose music or any form of granting Hitler a great exit. Tarantino avoids presenting Hitler as a "real image in the process of falling apart" and instead presents the Fuhrer as a constructed image, which has been destroyed beyond redemption. ${ }^{42}$ Tarantino here avoids replicating fascist aesthetics through granting any special importance to Hitler's death and denies him the possibility of returning in any form.

\footnotetext{
${ }^{37}$ Robert Dassanowsky, "Locating Mr. Tarantino Or, Who's Afraid of Metacinema?" in, Quentin Tarantino's Inglourious Basterds: A Manipulation of Metacinema, ed. Robert Dassanowsky (New York: Continuum, 2012), xii.

${ }^{38}$ Ian Kershaw, The "Hitler Myth": Image and Reality in the Third Reich (Oxford: Clarendon Press, 1987), 4.

${ }^{39}$ Ibid.

${ }^{40}$ Alexander D. Ornella, "Disruptive Violence as a Means to Create a Space for Reflection: Thoughts on Tarantino's Attempts at Audience Irritation," in Quentin Tarantino's Inglourious Basterds: A Manipulation of Metacinema, ed. Robert Dassanowsky (New York: Continuum, 2012), 234.

${ }^{41}$ Tarantino, Inglourious Basterds.

${ }^{42}$ Imke Meyer, "Exploding Cinema, Exploding Hollywood: Inglourious Basterds and the Limits of Cinema," in Quentin Tarantino's Inglourious Basterds: A Manipulation of Metacinema, ed Robert Dassanowsky (New York: Continuum, 2012), 28.
} 
The culmination of Inglourious Basterds is Tarantino's fantasy of using "cinema to bring down the Third Reich."43 The image is certainly fitting in-line with Joseph Goebbels' conception of the cinema as being directly involved in winning the war; Goebbels had stated that film must be given a "mission" in order "to conquer the world" 44 in a racial war with the Jewish controlled "American film" industry. ${ }^{45}$ Tarantino similarly transforms film into a "literal weapon," which can intervene directly in history. ${ }^{46}$ Shoshanna's revenge plot centers on the heroine's plan to burn her own cinema down using an archive of old nitrate film reels to create an inferno. Not only does Shoshanna burn down the theatre with the entire Nazi audience held captive, she also splices her own footage into the Nazi film "Nation's Pride", in which she directly responds to Zoller's boast as her giant, expressionist face fills the entire screen space:

Zoller: Who wants to send a message to Germany?

Shoshanna: I want to send a message to Germany. ${ }^{47}$

Shoshanna's face is shown in extreme close up, likening it to the "giant face" of the section's subtitle and creating a direct graphic match of Zoller's face, which had previously occupied the screen. This "giant face" could similarly be argued to refer to the extreme close ups which Tarantino provides of both Hitler and Goebbels' faces, as the two men laugh like sadistic children as they watch Zoller wantonly kill American soldiers on-screen. Hitler and Goebbels' final revenge is that the audience of the movie theatre is similarly anticipating a violent act committed against the Nazis in the same fashion that the two Nazis enjoy watching American soldiers die. Shoshanna mercilessly gives the cinephiles in the audience their desire for the "violence of images" in the same way that Tarantino provides his audience with a merciless and sadistic attack on passive, uncritical spectatorship. ${ }^{48}$ This final image of a burning cinema with barred doors has invited critics to compare the theatre to the crematoriums and gas chambers of the Holocaust, so Shoshanna merely replicates Nazi violence against Nazis. ${ }^{49}$ The audience in the theatre for Inglourious Basterds is engaging in the same vicarious pleasure drive, as the viewer watches a replication of the violence perpetrated by Nazis be inflicted upon the theatre's audience.

Tarantino has argued that in this final sequence, "you are in the same situation as the Nazis before the film.... I trap you in a cinema and show you a theater on fire." ${ }^{, 50}$ Effectively, Tarantino

${ }^{43}$ Quentin Tarantino and Gerald Peary, Quentin Tarantino: Interviews (Jackson: University Press of Mississippi, 2013), 179.

${ }^{44}$ Rentschler, 215.

${ }^{45}$ Ibid.

${ }^{46}$ Sharon Willis, "'Fire!' in a Crowded Theater: Liquidating History in Inglourious Basterds," in Quentin Tarantino's Inglourious Basterds: A Manipulation of Metacinema, 163-92, ed. Robert

Dassanowsky (New York: Continuum, 2012), 185.

${ }^{47}$ Tarantino, Inglourious Basterds.

${ }^{48}$ William Brown, "Counterfactuals, Quantum Physics, and Cruel Monsters in Quentin Tarantino's Inglourious Basterds." in Quentin Tarantino's Inglourious Basterds: A Manipulation of Metacinema, ed. Robert Dassanowsky (New York: Continuum, 2012), 264.

${ }^{49}$ Willis, 185.

${ }^{50}$ Eric Kligerman, "Reels of Justice: Inglourious Basterds, The Sorrow and the Pity, and Jewish Revenge Fantasies," in Quentin Tarantino's Inglourious Basterds: A Manipulation of Metacinema, ed. Robert Dassanowsky (New York: Continuum, 2012), 158. 
has situated the spectator in a position from which to reflect on "his/her ethical relation to the intersection between historical and cinematic violence" as the viewer witnesses Donny and another of the basterds violently gun down every spectator in the room as they try to escape. ${ }^{51}$ Similarly, the spectator obtains the unsettling pleasure of watching Hitler's face literally be torn to shreds by the basterds' bullets; in this final violent act, Tarantino sets out to satisfy the audience's desire to see this symbol of "absolute evil" be utterly destroyed, yet attacks the audience for desiring this same violence.

Michael Richardson argues in his essay "Vengeful Violence" that, in Inglourious Basterds, Tarantino is guilty of glorifying violence, and "replicates" fascist aesthetics through its inversion of Jews as perpetrators, and confirms "anti-Semitic stereotypes". 52 While the film certainly features scenes of excessive violence, Richardson's claim that the film uses "weak violence" (violence which functions merely as a formal device) comes across as rash in light of the scenes of violence, which have been covered in this analysis. ${ }^{53}$ Tarantino's depiction of violence in Inglourious Basterds is certainly "strong" in that it "acts on the mind by refusing it glib comfort and immediate resolutions." 54 When defining Tarantino's depiction of violence with respect to Landa's massacre, the Bear Jew's rampage, and the final massacre inside the theatre, the violence in the film can hardly be recognized as aesthetically beautiful, except the death of Shoshanna, which is romanticized in the style of Arthur Penn's Bonnie and Clyde. ${ }^{55}$ Shoshanna's death is played out in slow motion with the red tones of her blood matching her red dress and makeup. Richardson's argument concerning the replication of Jewish stereotypes, however, strikes a chord with a movie in which the (nearly) all-Jewish basterds are provided little to no back-story and certain character types emerge (such as the "muscle Jew" as the Bear Jew). ${ }^{56}$ While the perpetration of a "Jewish revenge fantasy" as a re-production (through reversal) of the crimes of the Nazi perpetrators is problematic, the film uses its visuals as a means of emphasizing some of the problems which stand at the heart of this violent fantasy as well as calling attention to the problematic representations of violence perpetrated by Americans in Hollywood anti-Nazi films.

Tarantino's film was a huge box office and critical success in both Germany and the United States; the film confirms what many German viewers already knew - that Americans are not necessarily the benevolent cosmopolitan heroes that Hollywood anti-Nazi films would represent them as. Tarantino's film relied extensively on international (and specifically German) resources, as Tarantino filmed most of the sequences on the former studio-grounds of the titanic UFA studio, which was the main national distributor and producer of films before the second World War had ended. UFA is most celebrated within film history circles as the progenitor of the Weimar era of films, which number Fritz Lang's Metropolis, M, Robert Wiene's The Cabinet of Dr. Caligari and F.W. Murnau's Nosferatu. The studio was formed during the final years of the

\footnotetext{
${ }^{51}$ Ibid., 157.

${ }^{52}$ Michael D. Richardson, "Vengeful Violence: Inglourious Basterds, Allohistory, and the Inversion of Victims and Perpetrators," in Quentin Tarantino's Inglourious Basterds: A Manipulation of Metacinema, ed. Robert Dassanowsky (New York: Continuum, 2012), 95 and 101.

${ }^{53}$ Ibid., 105.

${ }^{54}$ Ibid.

${ }^{55}$ Bonnie and Clyde. Directed by Arthur Penn (Warner Bros.-Seven Arts, 1967).

${ }^{56}$ Dassanowski, xvi.
} 
First World War as a means of combating the negative representations of Germans in American cinema and evolved into one of the largest film companies in the world. During the Third Reich, the studio was placed under state control and authorized by the propaganda minister, Joseph Goebbels. Tarantino draws on this legacy through casting entirely German speaking actors in the role of the Nazis, yet disassociates them from their traditional roles as the German actors are primarily involved in "dialogue-driven sequences" whereas the Americans are cast in roles which draw on the traditions of spaghetti westerns and the "dirty war" Hollywood movies of the 1960 's and 1970's and are primarily action oriented characters whose dialogue is often crass. ${ }^{57}$

At the heart of Tarantino's films is an argument that the National Socialist politics were politics of spectacle and of showmanship, and that fascist aesthetic forms are quite similar in structure to Hollywood's ideological and political goals. Inglourious Basterds confronts Hollywood's reliance on fascist aesthetics as elaborated by Eric Rentschler:

Nazi film theorists stressed the importance of kinetic images as well as galvanizing soundtracks. Music worked together with visuals to make the spectator lose touch with conceptual logic and discursive frameworks...The ideal film would spirit people away from the real world and grant viewers access to a pleasant compelling, and convincing alternative space. ${ }^{58}$

Rather than spirit its audience away from the real world, Tarantino's film refuses to allow the audience to leave the real world through establishing the fictional space of his film as a space of reflection where the audience is provoked to feel as if they are one of the sadistic Nazis, watching Tarantino's film for similar pleasures as those watching "Nation's Pride." Tarantino's habit of creating a pastiche of other films within his work is often seen as extending from his own fetish for film; however, the images to which Tarantino alludes in Inglourious Basterds are directly linked to Hollywood. Eric Kligerman argues that Tarantino's distortions to history allow the audience to reflect upon the "specters of other political catastrophes" which include a Gestapo officer deconstructing King Kong as an "allegory for American slavery," and Goebbels' belief that the Americans had won their Olympic gold on the backs of slaves. ${ }^{59}$ In addition, the practice of scalping, as well as the name of Aldo "the Apache," recalls the legacy of the Native American genocide. Similarly, Aldo carries a giant ring-like scar about his neck, which may hint at the practice of lynching in the American south. In this final sequence, Tarantino is confronting the audience with their own pleasure in witnessing "bad things happen to good people and worse things happen to bad people" and refuses to provide the audience with "catharsis" by opening up a "space for reflection and transformation. ${ }^{60}$

Tarantino's allusions function as a means of expressing the "imperialist racist tendency," which both Germany and America share.$^{61}$ In the opening sequence, Ennio Morricone's score is employed alongside a shot of Landa walking into Lapadite's house, which visually re-creates the

\footnotetext{
${ }^{57}$ Willis, 176.

${ }^{58}$ Rentschler, 217.

${ }^{59}$ Kligerman, 155 .

${ }^{60}$ Ornella, 221 and 216.

${ }^{61}$ Willis, 257.
} 
closing shot of John Ford's 1956 film The Searchers. ${ }^{62}$ John Ford's film tells the narrative of a man who must overcome his racism towards indigenous Americans in order to "rescue" his daughter from a murderous chieftain. The cinematic allusion draws the connection between American and German racism. Inglorious Basterds makes complicit references to American and Nazi films within the same shots, as in the opening sequence of "Revenge of the Giant Face" in which Shoshanna is gazing outside of a large window. There are images of her face reflected in the glass that are super-imposed overtop of the swastika banners and a poster of a Bridget von Hammersmark film (a fake film called "Fraulein Doktor"). This explicitly references the opening sequence of Penn's Bonnie and Clyde, as Tarantino uses close up shots of Shoshanna's lips in the mirror to open the scene in the same way that Penn begins his film, on an extreme close up of Bonnie's lips. This allusion to Bonnie and Clyde is no accident, as the film attempts to transform the two American gangsters into eternal images, first through a poem which Bonnie writes about the two gangsters' adventures and secondly through the iconic death scene, in which Penn slows down time and provides an excess of violence, as the two gangsters are ruthlessly gunned down by a group of Texas rangers. Penn gives Bonnie and Clyde a spectacular final exit in a similar fashion to fascist aesthetics and Tarantino is drawing on this iconography in order to establish the aesthetic connections between Nazi Germany and Hollywood.

Quentin Tarantino's Inglourious Basterds uses the history of the Third Reich and the figures of the SS colonel Hans Landa and Adolf Hitler not as a means of drawing out the "factual" history of the Third Reich, but rather to draw out the aesthetic legacy of the Third Reich. Through the film, Tarantino constructs an argument that the visual event of the "spectacle" was the "ultimate political manifestation" of the Third Reich, and that the Nazis have ultimately realized their dream through Hollywood's continued fascination with the enduring images of Hitler and Nazism. ${ }^{63}$ Tarantino's film represents the desires and images that both victims and enemies of the Third Reich have created in an alternate reality of Nazism, which has played out through Hollywood anti-Nazi films. Tarantino gives the American spectatorship precisely what popular viewing habits indicate and confronts the audience critically on the glorification and spectacles of violence which American audiences consume. As Meyer argues in her essay "Exploding cinema":

Hollywood...needs the Nazis...If the Jews had overpowered the Nazis, Hollywood cinema would not be what it is today...Tarantino seeks to show that the very cinema that believes itself to be a 'good' and democratic one builds its representations of the good-versus evil moral universe on simplistic binary structures that reproduce for Jewish characters the role that the Nazis assigned them, namely that of the eternal victim....Hollywood appropriates not only untainted sources but likewise liberally utilizes Nazi iconography in order to perpetuate its established conventions." 64

Tarantino's imagery in Inglourious Basterds self reflexively criticizes the tradition of images that have come before it, namely those of the anti-Nazi film and the genre's perpetuation of existing

\footnotetext{
${ }^{62}$ The Searchers. Directed by John Ford (Warner Bros, 1956).

${ }^{63}$ Rentschler, 223.

${ }^{64}$ Meyer, 18-21.
} 
stereotypes of Nazis and Jews. The near dominance that English speaking cinemas have held over cinematic representations of Hitler indicates an enduring fascination with the images of the leaders of the Third Reich, granting them Goebbels' final fantasy for the Nazi party as represented in a monologue delivered by a Goebbels puppet in Syberberg's Hitler:

All are rogues, including me. But if we are, let us be the greatest! And I'll see to it: in a hundred years, every word that each of us says, will be in a film! The part you play in it is up to you. I'll make you into legend, into myth; through your death if necessary! Yes, you can laugh down there, but try to follow my example: conquer the world in twenty-three years and change it from top to bottom. Yes, I'm the devil incarnate, yet a human being who laughed at Mickey Mouse just as you do. ${ }^{65}$

${ }^{65}$ Hitler - Ein Film Aus Deutschland. Directed by Hans Jurgen Syberberg (Omni Zoetrope, 1977). 


\section{Bibliography}

Bonnie and Clyde. Directed by Arthur Penn. Warner Bros.-Seven Arts, 1967.

Brown, William. "Counterfactuals, Quantum Physics, and Cruel Monsters in Quentin Tarantino's Inglourious Basterds." In Quentin Tarantino's Inglourious Basterds: A Manipulation of Metacinema, ed. Robert Dassanowsky (New York: Continuum, 2012), 247-70.

Cahiers Du Cinema Editorial Board. "Entretien Avec Quentin Tarantino: On N'a Pas Besoin Du Dynamite Quand on a De La Pellicule." Cahiers Du Cinema, 646th ser. (June 2009), 10-15.

Dassanowsky, Robert. "Locating Mr. Tarantino Or, Who's Afraid of Metacinema?" In Quentin Tarantino's Inglourious Basterds: A Manipulation of Metacinema, ed. Robert Dassanowsky (New York: Continuum, 2012), vii-xx.

Der Ewige Jude. Directed by Fritz Hippler. Germany: D.F.G. (Deutsche Filmherstellungs Und Vertriebs G.m.b.H., 1938.

Esslin, Martin. The Theatre of the Absurd. London: Methuen, 2001.

The Great Dictator. Directed by Charlie Chaplin. United Artists, 1941.

Hake, Sabine. Screen Nazis: Cinema, History, and Democracy. Madison: University of Wisconsin Press, 2012.

Hitler - Ein Film Aus Deutschland. Directed by Hans Jurgen Syberberg. Omni Zoetrope, 1977.

Inglourious Basterds. Directed by Quentin Tarantino. The Weinstein Company, 2009.

Kershaw, Ian. The "Hitler Myth": Image and Reality in the Third Reich. Oxford: Clarendon Press, 1987.

Kligerman, Eric. "Reels of Justice: Inglourious Basterds, The Sorrow and the Pity, and Jewish Revenge Fantasies." In Quentin Tarantino's Inglourious Basterds: A Manipulation of Metacinema, ed. Robert Dassanowsky (New York: Continuum, 2012), 135-62.

Meyer, Imke. "Exploding Cinema, Exploding Hollywood: Inglourious Basterds and the Limits of Cinema." In Quentin Tarantino's Inglourious Basterds: A Manipulation of Metacinema, ed. Robert Dassanowsky (New York: Continuum, 2012), 15-35.

Ornella, Alexander D. "Disruptive Violence as a Means to Create a Space for Reflection:Thoughts on Tarantino's Attempts at Audience Irritation." In Quentin Tarantino's Inglourious Basterds: A Manipulation of Metacinema, ed. Robert Dassanowsky (New York: Continuum, 2012), 215-45.

Rentschler, Eric. The Ministry of Illusion: Nazi Cinema and Its Afterlife. Cambridge, MA: Harvard University Press, 1996. 
Richardson, Michael D. "Vengeful Violence: Inglourious Basterds, Allohistory, and the Inversion of Victims and Perpetrators." In Quentin Tarantino's Inglourious Basterds: A Manipulation of Metacinema, ed. Robert Dassanowsky (New York: Continuum, 2012), 93112.

Ruehl, Martin A., and Karolin Machtans. Hitler--films from Germany: History, Cinema and Politics since 1945. New York: Palgrave Macmillan, 2012.

Schlipphacke, Heidi. "Inglourious Basterds and the Gender of Revenge." In Quentin Tarantino's Inglourious Basterds: A Manipulation of Metacinema, ed. Robert Dassanowsky (New York: Continuum, 2012), 113-33.

The Searchers. Directed by John Ford. Warner Bros, 1956.

Speck, Oliver C. "Is Tarantino Serious? The Twofold Image of the Auteur and the State of Exception." In Quentin Tarantino's Inglourious Basterds: A Manipulation of Metacinema, ed. Robert Dassanowsky (New York: Continuum, 2012), 193-213.

Syberberg, Hans Jürgen. Hitler, a Film from Germany. New York: Farrar Straus \& Giroux, 1982.

Tarantino, Quentin, and Gerald Peary. Quentin Tarantino: Interviews. Jackson: University Press of Mississippi, 2013.

Willis, Sharon. "'Fire!' in a Crowded Theater: Liquidating History in Inglourious Basterds." In Quentin Tarantino's Inglourious Basterds: A Manipulation of Metacinema, ed. Robert Dassanowsky (New York: Continuum, 2012), 163-92. 